\title{
PRZEKŁAD W DYDAKTYCE KOMPARATYSTYKI LITERACKIEJ
}

\begin{abstract}
Zarys treści. Artykuł dotyczy doświadczeń związanych z prowadzeniem zajęć na temat Literatura - translacja - powinowactwa kulturowe przeznaczonych dla studentów komparatystyki literackiej. Zawiera refleksje na temat sposobów pracy z przekładem i tekstem oryginalnym w grupie odbiorców o średniej lub zaawansowanej znajomości języków obcych, metod prezentacji takich zjawisk, jak strategie translatorskie, kategoria obcości, przekładalność dzieła literackiego. Obejmuje kwestie analizy porównawczej istniejących wersji danego utworu, przekładu intersemiotycznego, a także odczytywania tekstu rodzimego jako przedmiotu tłumaczenia, zawiera również obserwacje na temat roli, jaką przekład odgrywa w komparatystyce.
\end{abstract}

Doświęcone problematyce przekładu zajęcia pod tytułem Literatura - translacja - powinowactwa kulturowe przeznaczone są przede wszystkim dla studentów komparatystyki literackiej (Uniwersytet Jagielloński, Wydział Polonistyki), stanowią jedną z propozycji ćwiczeń specjalistycznych z literatury porównawczej. Uczęszczają na nie jednak również słuchacze innych kierunków polonistycznych, takich jak edytorstwo czy wiedza o kulturze, a także studenci innych filologii, wybierający konwersatorium jako zajęcia dodatkowe. Chętnie biorą w nim udział również studenci zagraniczni (w ubiegłym roku: Bułgarka, Rumunka i Węgier, w tym roku Norweżka, Rosjanka i dwie Czeszki). W zajęciach uczestniczą studenci różnych lat, a zatem prowadzący musi brać pod uwagę rozmaity stopień opanowania podstawowego warsztatu badawczego literaturo- i językoznawczego, a także

* Autorka jest laureatką konkursu Fundacji na Rzecz Nauki Polskiej o stypendium krajowe dla młodych naukowców na rok 2004, z przedłużeniem na 2005. 
głębsze lub bardziej powierzchowne obeznanie słuchaczy z terminologią teoretycznoliteracką i zagadnieniami poetyki.

W grupie przeważają poloniści, a więc przy pracy z przekładem pojawia się zasadniczy problem, jakim jest stopień znajomości języków obcych: w większości przypadków jest to znajomość podstawowa lub średnio zaawansowana, toteż dobór tekstów do analizy i refleksji krytycznej musi uwzględniać także dostępność oryginału dla przeciętnego odbiorcy. Jednocześnie konieczne jest ośmielenie studenta do spojrzenia na tekst w wersji pierwotnej, zachęcenie go do podjęcia wysiłku lektury utworu oryginalnego. W tej sytuacji niemal automatycznie dochodzi do uruchomienia mechanizmów komparatystycznych, gdyż odbiór tekstu odbywa się zwykle na drodze porównania wersji pierwotnej i sąsiadującego z nią przekładu. Odkrycie przydatności kontaktu z dziełem w języku wyjściowym przyczynia się do coraz częstszego wśród studentów sięgania po dwujęzyczne edycje zarówno tomików poezji, jak i utworów prozą.

Warunkiem uczestnictwa w zajęciach nie jest doskonała znajomość jednego z języków analizowanych dzieł (ze względu na przygotowanie zawodowe prowadzącej są to przede wszystkim utwory włoskie, angielskie, francuskie, sięgamy jednak również po teksty rosyjskie, hiszpańskie czy łacińskie), ale przede wszystkim świetne opanowanie, świadomość i „wyczucie” języka ojczystego jako narzędzia poznania i oceny przekładów. Zazwyczaj jednym z pierwszych tekstów, jaki otrzymują do analizy studenci, są fragmenty Biblii w różnych tłumaczeniach: wybrane urywki Pieśni nad pieśniami czy Psalmów stanowią dowód na to, że przekład towarzyszy nam na co dzień - i niekiedy nawet nie traktujemy go jako tekstu „zapożyczonego”, tak głęboko wrósł w kulturę - a z drugiej strony przewrotnie ukazują, że rozmowa o przekładzie jest możliwa nawet w sytuacji, gdy dostęp do oryginału jest znacznie - żeby nie powiedzieć zupełnie - ograniczony. W takim wypadku refleksja badawcza koncentruje się nie na różnicach i podobieństwach pomiędzy tekstem wyjściowym a tłumaczeniem, a na relacjach zachodzących pomiędzy poszczególnymi wersjami. Przedmiotem zainteresowania stają się zatem modyfikacje poszczególnych obrazów, obecność i formy terminologii teologicznej, innowacje kulturowe, takie jak, na przykład, wprowadzenie pojęcia Hadesu na określenie zaświatów w przekładzie Pieśni nad pieśniami Zygmunta Bytkowskiego-Bromberga (1924).

Podkreślić należy, że celem zajęć nie jest praktyczna nauka tłumaczenia literackiego, lecz uwrażliwienie odbiorcy na przekład, na zjawiska zachodzące w procesie transformacji oryginału na język docelowy, na trudności, jakie tekst stawia przed tłumaczem, na wypływające z niego możliwości 
interpretacyjne. Metody pracy, na przykład analiza porównawcza, są zbliżone do metod nauczania przekładu (Kozłowska 2000: 72-73). Zasadniczo studenci pracują nie tylko nad tekstem oryginalnym i jego jednym przekładem, ale posługują się, jeśli to możliwe, kilkoma tłumaczeniami. Czasami są to różne wersje polskie, jak w przypadku Invitation au voyage Charlesa Baudelaire’a, które spolszczyli Czesław Jastrzębiec Kozłowski, Ewa Wende, Maria Leśniewska, czy fragmentów Alicji w Krainie Czarów Lewisa Carrolla w przekładach Marii Morawskiej, Antoniego Marianowicza, Macieja Słomczyńskiego i Roberta Stillera (w ostatnim przypadku można dokonać ciekawych obserwacji na temat roli adresata tłumaczenia w procesie kształtowania tekstu docelowego). Niekiedy przedmiotem analizy są różne wersje językowe danego utworu, na przykład polska (Jana Zycha) i włoska (Roberta Paolego) wiersza Arte poetica Pabla Nerudy albo В Италии Josifa Brodskiego w autorskim przekładzie na angielski i w polskiej wersji pióra Stanisława Barańczaka. Oczywiście posłużenie się przekładem autorskim pociąga za sobą konieczność refleksji teoretycznej nad sytuacją, w której twórca tekstu występuje $\mathrm{w}$ roli optymalnego tłumacza, mającego dostęp do nieprzeniknionej „intencji autora”.

Ze względu na konwersatoryjny charakter zajęć wybierane do lektury teksty mają na ogół niewielką objętość, tak aby można je było przeczytać i omówić podczas jednego czy dwóch dziewięćdziesięciominutowych spotkań. W szczególny sposób nadają się do tego rodzaju pracy utwory poetyckie, proza natomiast pojawia się w urywkach, stanowiących zamknięte całości (rozdział, ustęp, akapit). Z większymi fragmentami studenci zapoznają się wcześniej, przedstawiając na zajęciach wypływające $\mathrm{z}$ ich analizy wnioski. Rzecz jasna, o wyborze tekstów do refleksji nie decyduje kryterium objętościowe, ale reprezentatywność utworu oryginalnego, niezwykłość zaproponowanych przez tłumacza rozwiązań interpretacyjnych, a także wielość przekładów pojawiających się w ciągu wieków.

Początkowo, aby zachęcić studentów do przyjęcia postawy krytycznej wobec tłumaczenia, przekłady dobierane są na zasadzie stosunkowo prostej opozycji „dobry” - „zły”: wartościowanie odbywa się wówczas na podstawie literackiej wrażliwości słuchaczy; zwykle zdecydowanie odrzucają oni wersje mniej zgrabne, epatujące stylistycznymi dziwolągami, zawierające błędy językowe lub przeinaczające ostateczną wymowę utworu. Nawet w przypadku tłumaczeń nieudanych czy nietrafnych zachęcam studentów do poszukiwania tego, co w danej wersji wartościowe i zadowalające. Wraz z upływem czasu (cykl zajęć trwa rok) zestawienia tekstów są coraz trudniejsze, przedmiotem analizy stają się na przykład serie dobrych przekładów z róż- 
nych epok albo tłumaczenia dokonane przez rozmaitych autorów i eksponujące coraz to inne cechy oryginału. Szczególną uwagę poświęca się wówczas temu, co w danym tekście wydaje się nieprzetłumaczalne i chwytom, jakimi posługuje się tłumacz, aby nieprzekładalne przełożyć.

Tradycyjnie przebieg zajęć oscyluje wokół następującego schematu: najpierw odbywa się zapoznanie $z$ tekstem oryginalnym, niekiedy połączone z próbą identyfikacji autora i/lub umieszczenia tekstu w kontekście historycznoliterackim (podanie przybliżonego czasu powstania utworu, określenie gatunku), wyjaśnienie ewentualnych nieścisłości wynikających z nieznajomości języka, krótka analiza i interpretacja utworu, w czym zwykle aktywny udział biorą studenci znający język wyjściowy. Kolejnym krokiem jest określenie trudności, jakie tekst może nastręczyć tłumaczowi. Potem następuje lektura towarzyszących tekstowi oryginalnemu przekładów (nazwiska tłumaczy zostają podane wcześniej lub znów stanowią przedmiot krótkiej zagadki) i pogłębiona analiza porównawcza tłumaczeń wobec oryginału i siebie nawzajem, obejmująca kwestie wierności wobec tekstu wyjściowego, użytych strategii translatorskich, zrozumiałości tekstu docelowego, jego przeznaczenia oraz artyzmu. Jednak przedmiotem lektury krytycznej są podczas zajęć nie tylko utwory obce w przekładzie na język polski, ale również dzieła rodzime $\mathrm{w}$ tłumaczeniach na inne języki. W takiej sytuacji grupa dokonuje lektury tekstu, zwracając szczególną uwagę na te elementy, które, według terminologii Stanisława Barańczaka (2004: 20), stanowią dominantę semantyczną utworu i które powinny przetrwać w przekładzie. Dopiero później następuje analiza tekstów tłumaczonych, ich wartości lub mankamentów. Umiejętność interpretacji utworów rodzimych ułatwia krytyczny odbiór tekstów obcych i jest ważnym kryterium w porównawczej krytyce przekładu: komparatysta powinien mieć kompetencje pozwalające mu wybrać przekład, który jest wierny duchowi oryginału, a jednocześnie może funkcjonować jak pełnoprawne dzieło literackie w języku docelowym.

Ze względu na towarzyszące porównawczej lekturze tekstów niebezpieczeństwo popadnięcia w krytykanctwo proponuję w pewnym momencie ćwiczenie, które pozwala studentom przekonać się bezpośrednio, jak poważnym zadaniem jest przekład literacki. Ćwiczenie polega na chwilowym pozbawieniu ich wszechmocnej roli odbiorcy, mającego możliwość interwencji w każdy dowolny fragment przekładu (Balcerzan 1998: 113). Służy temu odbywająca się w podgrupach ,językowych" próba tłumaczenia a vista popularnego wiersza Wisławy Szymborskiej, zatytułowanego Portret kobiecy. Wiadomo, jak wielkie wyzwanie stanowi ten utwór dla tłumacza. 
Pracę nad tekstem rozpoczyna pytanie o to, czy jest to łatwe, czy trudne do przełożenia dzieło. Zazwyczaj w pierwszej chwili rozlega się chór głosów, stwierdzających, iż tekst jest „prosty, bo zawiera wiele wyrażeń z języka potocznego”, „brak w nim skomplikowanych środków artystycznych”, „jest zrozumiały”, „nie ma rymów”. Poszczególne zespoły (na ogół włoski, angielski, francuski i niemiecki) zabierają się zatem do pracy i po chwili okazuje się, że wiersz wcale nie jest łatwy, a już pierwszy wers wydaje się przeszkodą niemal nie do pokonania w językach, w których konieczna jest obecność podmiotu w zdaniu. Później pojawia się problem frazeologizmów rzeczywistych (nie ma głowy na karku, na litość boska) i pozornych (na dobre, na niedobre), zamkniętych kropką pytań oraz zjawisk kulturowych, takich jak wybór alkoholu, jaki ma zastąpić kieliszek czystej. Przekładu - nie literackiego, a filologicznego - dokonują w całości zwykle te podgrupy, w których znajdą się radzący sobie z przymusem tłumaczenia studenci filologii obcych; komparatyści zwykle kompetentnie i przekonywająco bronią tez o nieprzekładalności utworu lub jego części. Podczas kolejnego spotkania mają okazję przyjrzeć się Portretowi kobiecemu w przekładach tłumaczy zawodowych, na przykład Karla Dedeciusa na niemiecki, Pietra Marchesaniego na włoski, Piotra Kamińskiego na francuski, Magnusa Krynskiego i Roberta Maguire’a na angielski, jak również porównać zastosowane strategie i uzyskane efekty końcowe.

Innym, ważnym i ściśle związanym z poprzednio wymienionymi kwestiami, celem konwersatorium jest rozbudzenie ciekawości badawczej i swoistej nieufności odbiorcy, stykającego się przeważnie z literaturą powszechną w formie zapośredniczonej. Chodzi zatem o skłonienie studenta do postawienia sobie pytania: czy utwór, który czytam, ma tę samą wymowę, co jego wersja oryginalna? Refleksja tego rodzaju stanowi również dodatkową motywację do zaangażowania w naukę języków obcych i związane z nią odkrywanie innych kultur.

Jednym z poruszanych podczas zajęć problemów jest zagadnienie przekładu intersemiotycznego, a więc takiego, w którym dochodzi do interpretacji znaków językowych za pomoca znaków pozajęzykowych systemów znakowych (Jakobson 1989, t. 1: 373). Przedmiotem refleksji stają się tutaj dzieła literackie - lub ich fragmenty, które zainspirowały twórców posługujących się pozawerbalnymi środkami ekspresji, jak na przykład Katedra Maryi Panny w Paryżu Victora Hugo, stanowiąca kanwę współczesnego musicalu Notre Dame Riccarda Cocciante (ciekawy punkt wyjścia do rozważań na temat zjawiska kiczu), albo epizod uwolnienia Angeliki z X Pieśni Orlanda Szalonego Ludovica Ariosta w reinterpretacjach malarskich w XIX wieku 
(zob. Płaszczewska 2000: 71-89), gdzie podstawowym problemem - jeśli pominąć kwestię szczególnego charakteru polskiej wersji poematu pióra Piotra Kochanowskiego - będzie transmutacja konieczna do ukazania niewypowiedzianego (Eco 2003: 327).

Niejako „ubocznym efektem” zajęć jest działalność translatorska samych studentów, próbujących własnych sił w przekładzie. Próby są mniej lub bardziej udane, ale stanowią interesujące świadectwo zainteresowania słuchaczy problematyką tłumaczenia, są znakiem podjęcia wyzwania, jakie niesie ze sobą tekst oryginalny i przekłady innych tłumaczy. Przykładem zmagań studenckich z przekładem niech będą cytowane w Aneksie dwa fragmenty: dość zgrabnie, poza drobnymi niezręcznościami, jak rufom uchodzące zatoki czy nadużycie rymów gramatycznych, przetłumaczony przez Annę Piróg wiersz Paula Valéry'ego, lub fragmenty Mythopoei J. R. R. Tolkiena pomysłowo spolszczone przez Zofię Hulko (obie panie są obecnie studentkami III roku komparatystyki).

W ramach konwersatorium słuchacz ma także okazję zapoznać się $\mathrm{z}$ podstawowymi zagadnieniami translatologii. $\mathrm{W}$ toku zajęć poruszane są między innymi takie problemy, jak: rola przekładu w komparatystyce literackiej, strategie translatorskie, kategoria obcości czy zagadnienie przekładalności. Studenci otrzymują listę podstawowych lektur, które mają ułatwić im pracę z przekładem, oswoić z terminologią fachową i zapoznać ze współczesnymi i historycznymi tendencjami przekładoznawczymi. Niejednokrotnie komentarz bądź uzupełnienie dyskusji nad utworami literackimi w przekładzie stanowi refleksja nad wypowiedziami teoretyków i praktyków translacji. Poznawanie teorii przekładu rozpoczyna zwykle lektura kontrowersyjnego, lecz stanowiącego wartościową pożywkę intelektualną i inspirującego do rozważań Małego, lecz maksymalistycznego manifestu translatologicznego Stanisława Barańczaka (Barańczak 2004: 13-62). Ten tekst okazuje się istotny również ze względu na pojawiającą się konieczność uświadomienia odbiorcy, jak często styka się z przekładem i zwrócenia uwagi na to, że ktoś tego tłumaczenia dokonuje: charakterystyczny wydaje się fakt, iż relacjonując kwerendę na temat przekładów z literatury włoskiej dostępnych w księgarniach, jedna ze studentek neofilologii, słuchaczka V roku, a więc osoba, od której należałby się spodziewać szczególnej wrażliwości w tej dziedzinie, wcale nie zainteresowała się nazwiskami tłumaczy. Podobny brak świadomości translatologicznej przekonuje mnie o słuszności podjęcia poświęconych zjawisku przekładu zajęć dla studentów, dla których tłumaczenie jest zwyczajną częścią świata lektur, w jakim się obracają. Być może dzięki ćwiczeniom pod hasłem Literatura - translacja - powinowac- 
twa kulturowe uda im się odkryć urok przekładu, a także zdać sobie sprawę $z$ tego, iż translatologia to nie tylko samodzielna dyscyplina humanistyczna, ale również jedna $\mathrm{z}$ odmian szeroko pojętej komparatystyki literackiej.

\section{Literatura}

Balcerzan, E., 1998, Literatura $z$ literatury (strategie tłumaczy), Katowice. Barańczak, S., 2004, „Mały, lecz maksymalistyczny Manifest translatologiczny albo: tłumaczenie się z tego, że się tłumaczy wiersze również w celu wytłumaczenia innym tłumaczom, iż dla większości tłumaczeń wierszy nie ma wytłumaczenia”, [w:] S. Barańczak, Ocalone w tłumaczeniu, wyd. 3, Kraków 2004, s. 13-62.

Eco, U., 2003, Dire quasi la stessa cosa. Esperienze di traduzione, Bompiani, Milano.

Jakobson, R., 1989, „O językoznawczych aspektach przekładu”, [w:] R. Jakobson, $W$ poszukiwaniu istoty języka, t. 1, Warszawa, s. 372-381.

Kozłowska, Z., 2000, „Nauczanie tłumaczenia pisemnego na język obcy a nauczanie tłumaczenia pisemnego na język ojczysty", [w:] O nauczaniu przekładu, red. A. Setkowicz, Warszawa, s. 62-77.

Płaszczewska, O., 2000 „«uggiero libera Angelica» (L. Ariosto, Orlando Furioso, X) nelle realizzazioni di Ingres e Delacroix. Sulla traduzione intersemiotica", [w:] Między oryginałem a przekładem, VI: Przekład jako promocja literatury, red. M. Filipowicz-Rudek i in., Kraków, s. 71-89.

\section{Aneks}

\section{Paul Valéry (1871-1945), Hélène}

Azur! C'est moi... Je viens des grottes de la mort

Entendre l'onde se rompre aux degrés sonores.

Et je revois les galères dans les aurores

Ressusciter de l'ombre au fil des rames d'or.

Mes solitaires mains appellent les monarques Dont la barbe de sel amusait mes doigts purs; Je pleurais. Ils chantaient leurs triomphes obscurs Et les golfes enfuis aux poupes de leurs barques. 
J'entends les conques profondes et les clairons

Militaires rythmer le vol des avirons;

Le chant clair des rameurs enchaîne le tumulte.

Et les Dieux, à la proue héroïque exaltés,

Dans leur sourire antique et que l'écume insulte,

Tendent vers moi leurs bras indulgents et sculptés.

\section{Helena}

(przeł. Anna Piróg, I rok komparatystyki, UJ)

Oto ja... O błękicie! Z śmierci idę jaskiń, By słyszeć jak fala o brzeg dźwięczny pryska

I dostrzegam galery w pierwszych świtu błyskach,

Ich, powstających z mroku, złotych wioseł blaski.

Moje ręce samotne władców wzywające...

Ich solny zarost cieszył me palce dziewicze.

Płakałam. Oni swoje triumfy tajemnicze

I zatoki sławili, rufom uchodzące.

Słyszę muszle i trąby, które wojnę głoszą, A wiosła w rytm ich grania w górę się unoszą. Pieśń wioślarzy ujarzmia bałwany wzburzone,

A wzruszeni bogowie na dziobach okrętów $\mathrm{W}$ uśmiechu swym antycznym i wśród piany kłębów Pobłażliwe ramiona dają mi rzeźbione.

\section{J. R. R. Tolkien, Mythopoeia (fragment)}

To one who said that myths were lies and therefore worthless, even though "breathed through silver"

\section{Philomythus то Misomythus}

You look at trees and label them just so, (for trees are 'trees', and growing is 'to grow'); you walk the earth and tread with solemn pace one of the many minor globes of Space:

a star's a star, some matter in a ball compelled to courses mathematical 
amid the regimented, cold, Inane, where destined atoms are each moment slain.

At bidding of a Will, to which we bend (and must), but only dimly apprehend, great processes march on, as Time unrolls from dark beginnings to uncertain goals; and as on page o'erwitten without clue, with script and limning packed of various hue, and endless multitude of forms appear, some grim, some frail, some beautiful, some queer, each alien, except as kin from one remote Origo, gnat, man, stone, and sun. God made the petreous rocks, the arboreal trees, tellurian earth, and stellar stars, and these homuncular men, who walk upon the ground with nerves that tingle touched by light and sound. The movements of the sea, the wind in boughs, green grass, the large slow oddity of cows, thunder and lightning, birds that wheel and cry, slime crawling up from mud to live and die, these each are duly registered and print the brain's contortions with a separate dint [...].

\section{Mythopoeia (fragment)}

(przeł. Zofia Hulko, I rok komparatystyki, UJ)

Temu, kto powiedział, że mity to kłamstwa miłe dla ucha, lecz bez wartości.

Philomythus do Mizomytha

Patrzysz na drzewa i tak je nazywasz

(bo rośnięcie to „rosnąć”, „drzewami” są drzewa);

stawiasz krok uroczysty, stąpając po ziemi, planecie jednej z pomniejszych w Przestrzeni:

gwiazda jest gwiazdą, materią w kuli,

zmuszoną do kursów w niewzruszonej Próżni

zimnej; po orbitach dawno wyznaczonych,

gdzie co chwilę giną skazane atomy.

Z nakazu Woli, której się kłaniamy

(musimy), lecz tylko mgliście zrozumianej, wielkie procesy się toczą, gdy czas się przemienia 
z ciemnych początków w stronę niepewnego przeznaczenia;

tak jak strona bez wskazówek zapisana, tam skrypt, karta iluminowana i ukazują się formy niezliczone ponure, kruche, wątłe, piękne, udziwnione, każdy kształt inny, jednak odległa je łączy Origo - komar, człowiek, kamień i słońce. Bóg stworzył drzewne drzewa i skały kamienne, gruntowną ziemię i jeszcze gwiazdy gwiezdne, człowieczych ludzi, którzy ziemię przemierzają, o nerwach, co światłem dotknięte dźwiękiem rozbrzmiewają. Przypływy morza i gałęzie kołysane wiatrem, dziwną powolność krów wielkich i zieloną trawę, ptaki, co krążą i krzyczą, błyskawice, burze, szlam wypełzająjcy z dna, żeby żyć i umrzeć, a każde $\mathrm{z}$ nich dokładnie ułożone jest w załomach mózgu osobno rzeźbione [...].

\section{Translation in teaching comparative literature (summary)}

The article presents experiences connected with teaching the course Literature - translation - cultural affinities to the students of comparative literature. The course focuses on comparative reading of translations. The article also includes reflections on methods of dealing with a translation and an original text in a group of receivers with intermediate or advanced knowledge of foreign languages. It also demonstrates how to present such translation phenomena as translation strategies, the concept of strangeness as well as translatability of a literary work. It embraces problems connected with comparative analysis of attested translations of a specific piece of literature. Such aspects as intersemiotic translation and perceiving a text in the mother tongue as a prospective aim of translation are also investigated. The article includes certain observations on the place of translation in comparative literature. In the Appendix we can find literary translation samples performed by two participants of the course. 